\title{
Daily Life at the Hermitage in Mechelen at the Time of Maria Petyt (1657-1677)
}

\author{
Michel van Meerbeeck
}

\section{Introduction}

There are many publications about Maria Petyt, particularly in the fields of theology and spirituality. ${ }^{1}$ This is not surprising, because the contents of her work $^{2}$ are very intriguing from that point of view, so they seem to attract most attention. But by confining oneself to these fields one runs a real risk of drawing a distorted picture of Maria. Moreover, her work cannot be understood properly if certain historical elements are overlooked.

One might wonder why historical research on Maria Petyt has had such limited success. Is it because of a lack of sources? An attentive reading of her various works provides a lot of material for a biography, especially if one studies the whole corpus, not only the autobiography. Research so far has hardly gone beyond this initial stage. There is one fortunate exception: the study conducted by A. Staring. ${ }^{3}$ This has still to be considered important along with the later significant work by A. Deblaere. ${ }^{4}$

The archives of the hermitage - filed systematically but, except for a few copies, not handed down to us - are among the possible sources. ${ }^{5}$ The archives of the Carmelites at Mechelen, which were already admired by A. Sanderus $^{6}$ during Maria's lifetime, are still available. However, the documents that were preserved were not chronicles or visitation reports but a surprising number of notarial acts and financial information. Not only do they confirm what we already know from Maria's texts, they also make it possible to understand the financial and material basis of life at the hermitage. ${ }^{7}$ Other information

1 For a substantial bibliography, see Lowyk (1991) 9-12, 47-50 and Persoons (2009) 277-280.

2 Petyt (1683).

3 Staring (1948).

4 Deblaere (1962).

5 E.g. Boxmeer, Nederlands Carmelitaans Instituut, Provincia Flandro Belgica, convent of Mechelen: acts of 9 September 1707 .

6 Sanderus (1727) 238.

7 We hope to give an overview of these sources kept in several archives in a further study.

(C) MICHEL VAN MEERBEECK, 2015 | DOI 10.1163/9789004291874_005

This is an open access chapter distributed under the terms of the Creative Commons AttributionNoncommercial 3.o Unported (CC-BY-NC 3.o) License. 
can be drawn from the correspondence of Michael of St. Augustine, most of which is kept in the general archives of the Carmelite Order in Rome. ${ }^{8}$

In 1999 by chance we were able to trace the ordinances of the hermitage of Mechelen, formulated by Michael of St. Augustine. We hope to publish them soon. This normative source contains a treasure of information about the hermitage. However, one has to exercise caution: there can be a big difference between the norm and one's perception of the norm. ${ }^{9}$

In this limited paper I outline daily life in the hermitage of Mechelen. First I sketch the context and then focus on the sisters in the hermitage. Their physical life will be described and thereafter their spiritual life.

\section{The Monastery of the Carmelites in Mechelen}

The monastery of the White Friars of Mechelen reached its zenith in the early years of its reform. ${ }^{10}$ It had been devastated during the religious wars, but after the destruction came a period of renewal. The first years after Maria Petyt's arrival at Mechelen saw the restoration of the church, and she was a witness to all the mess from the work in the church. ${ }^{11}$

Round about 1655 the monastery was a flourishing community which engaged in mentoring fraternities, offering spiritual guidance, hearing confessions, helping prisoners, nursing the sick, preaching and training the third order in Mechelen. The original list of the 57 members of the community in 1654 was found recently. ${ }^{12}$ Michael of St. Augustine, ${ }^{13}$ Maria's spiritual director,

8 E.g. Rome, Archivum generale ord. carmelitarum, II. Flandro Belgica, conventus Brussel, Michael of St. Augustine to Seraphinus of Jesus and Mary, Brussels 24 February 168o. Parts of this letter were published by Hoppenbrouwers (1960) 403 and Motta Navarro (1960) 59 . I thank Emanuele Boaga O.Carm, general archivist († 2013).

9 Ordonnantiën. Until the publication of our overview we quote from the original folios of this document.

10 The obituaries and the reports (Mechelen, Stadsarchief, $c c$, 31: s.f.) of the White Friars of Mechelen claim that the convent was reformed in $165^{2}$, along with the entire Belgian province. But Panzer (2006) 270 mentions the convent of Tienen as the last reformed monastery of the province (1656). Petyt (1683) vol. 2, 173 . Leuven, KADOC, Provinciaal archief van de Vlaamse Minderbroeders, 2.2.291: J. van Meerbeek, Register ende specificatie van allen de landen, bemden, bosschen, aerden ende opstallen der convente vande Patres Carmeliten binnen Mechelen toebehoorende (1653), s. XVII. Recently returned to the Archivium archiepiscopalia of Mechelen, cf. Laenen (1914) XII. Hoppenbrouwers (1949); Deblaere (1980); Possanzini (1998); Martinez Carretero (1991); Valabek (2008). 
initiated the reform of the monastery. In 1656 he became provincial but stayed in Mechelen, where he was succeeded as prior by Daniel of the Virgin Mary. ${ }^{14}$ The latter wrote a reflection on the rule for the third order ${ }^{15}$ and one for the hermitage of Termuylen. ${ }^{16}$

As we know, the Carmelites through the centuries remained nostalgic about their hermitic life. In Mechelen George Peeters got permission to lead a sort of hermit life inside the monastery. ${ }^{17}$ In the new constitutions the hermitic life in the desert was highly valued. ${ }^{18}$ This stems from the revival of hermitages after the religious wars. ${ }^{19}$

During his visitation in $165^{2}$ the prior general encouraged the establishment of a hermitage in Liedekerke. After Daniel of the Virgin Mary, Michael was also involved in the construction of Termuylen. ${ }^{20}$ Many benefactors, including the monastery in Mechelen, provided the necessary funds. Anna van Liebeke, who donated an annuity for Maria, founded and paid for a cell. ${ }^{21}$ In her will Maria appointed the monastery of Termuylen her heir in case the projected hermitage of Mechelen should come to nought. ${ }^{22}$

The 17th century was also a century of record keeping. The acts of the Carmelite monastery were copied and declared authentic. Heavy books still testify to the administrative reform. ${ }^{23}$ Today we know that the monastery owned four

\footnotetext{
14 Hoppenbrouwers (1934); Wijnhoven (1966); Melchior a Sancta Maria (1968).

15 Daniel of the Virgin Mary (1646).

16 Boxmeer, Nederlands Carmelitaans Instituut, Provincia Flandro-Belgica, convent of Liedekerke: Ordo vitae regularis pro conventu eremitico Bmae Virginis Mariae dictae ad Mulam.

The attestatio de vita V.P. Gregorii Petri was kept in the archive of the convent, cf. Mechelen, Stadsarchief, Archieven van het rijksarchief Antwerpen in bewaring gegeven, Geschoeide karmelieten van Mechelen, 11, 76. His biography was published in James of the Passion (1681) 131-133.

18 Constitutiones (1656) 7-13.

19 Sainsaulieu (1974).

20 Boxmeer, Nederlands Carmelitaans Instituut, Provincia Flandro-Belgica, convent of Liedekerke; Bronselaer (1954) 34-41.

$21 \quad$ Kort begryp van de historie (1753) 41-43. Boxmeer, Nederlands Carmelitaans Instituut, Flandro-Belgica, convent of Liedekerke: Liber diarius carmeli eremitici S. Josephi in Sylvalikerkana, 19-22. A copy of the act of 6 April $165_{2}$ is in Boxmeer, Nederlands Carmelitaans Instituut, Provincia Flandro-Belgica, convent of Liedekerke but the minutes of this act are in Gent, Rijksarchief Gent, Oud Notariaat, 1270.

Boxmeer, Nederlands Carmelitaans Instituut, Provincia Flandro-Belgica, convent of Mechelen: declaration by F. Engrand, 16 December 1710.

Cf. n. 7 .
} 
houses on the Veemarkt. ${ }^{24}$ One of these, called St. Joseph house, was sold to pay for the reconstructions. ${ }^{25}$ The copyist also mentions a small house called De Cluyse, which was located next to the church on the Veemarkt. The now lost title deed dated from the $15^{\text {th }}$ century. ${ }^{26}$

\section{De Cluyse}

The debate about the origin of the hermitage started in the 18th century and still continues. ${ }^{27}$ What we know for certain is that the building was called a hermitage before Maria's arrival. ${ }^{28}$ Jan Abroex had been living there for many years and had extended his lease in $1649 .{ }^{29}$ After his death the premises were vacant and in October 1657 jouffrouw Maria le Petit moved into the house, which she rented for $80 \mathrm{fl.} .^{30}$ The dates when the rental fell due were Bamisse (feast of St. Bavo, 1st October) and St. Jansmisse (feast of St. John the Baptist, 24 th June). Some reconstruction work was done in 1650 , but immediately after Maria's death the house was fully renovated. It adjoined the church and the sisters were able to follow the offices, probably through a window in their oratory. Some scandalmongers talked about an entrance, through which the fathers came to visit the sisters at improper hours. The vicar, a Jansenist, wanted to verify this but gave up, having achieved nothing. ${ }^{31}$ On the other side of the Cluyse was the St. Joseph house. In 1659 the monastery bought back its former

24 Mechelen, Stadsarchief, Archieven van het rijksarchief Antwerpen in bewaring gegeven, Geschoeide karmelieten van Mechelen, 6, 91.

25 Mechelen, Stadsarchief, Augustijnen, 40 B or: act of 27 February 1613.

26 Mechelen, Stadsarchief, Archieven van het rijksarchief Antwerpen in bewaring gegeven, Geschoeide karmelieten van Mechelen, 1, fol. 168r-169r, cop.; Mechelen, Stadsarchief, Archieven van het rijksarchief Antwerpen in bewaring gegeven, Geschoeide karmelieten van Mechelen, 6, 91.

27 Persoons (2009) 260-263.

28 Petyt (1683) vol. 1, 101.

29 Mechelen, Archivum archiepiscopalia, Geschoeide karmelieten van Mechelen, 20, 180.

30 'Is bewoont bij Jouffrouwe Maria Le Petit ingegaen Bamisse XVIC sevenenvijfftich, annue LXXX fl.', Mechelen, Stadsarchief, Archieven van het rijksarchief Antwerpen in bewaring gegeven, Geschoeide karmelieten van Mechelen, $5,169$.

$31 \quad$ Petyt (1683) vol. 1, 80. In the Latin version, Deblaere (1962) 316, and in Michael of St. Augustine (1681) 18, the 'man of quality' is identified as the parish priest. Christian de Cort (1611-1669) was involved with the mystic Antoinette Bourguignon and the Jansenists of Nordstrand; De Baar (2004) 77-99; Adriaensen (1988) 104-116. 
property. ${ }^{32}$ The goal was probably to give the community an adequate monastery with more space and a private chapel, as prescribed in the ordinances. During those years agreements about separating walls were also signed with other neighbours. ${ }^{33}$

Apart from the yard, the hermitage included communal rooms like a refectory (rarely used), a kitchen, a consulting room, and an oratory, the interior of which was affectingly simple: an altar with 'the devoted mother with her Jesus in her arms', between candlesticks and a crucifix of poor quality. The cells were just as poorly furnished: a straw mattress, white sheets, pillow and blankets, a small table and a chair, as well as a prie-dieu. A crucifix, an aspersorium and a picture of Our Lady were the only decorations. Stationery, some books according to the wishes of the mother superior, a lamp or a candle, a basin and a towel completed the inventory. ${ }^{34}$

The hermitage had a special statute: Maria Petyt was and remained a spiritual daughter rather than a proper nun, and a member of the Third Order of the Carmelites. She followed the first rule ${ }^{35}$ and took no solemn vow of poverty. ${ }^{36}$ Although the women were not looking for contact with the outside world, there was no enclosure. Because of these conditions the worldly authorities decided that soldiers could be quartered in this house: after all, the women were daughters and not cloistered sisters. ${ }^{37}$ This statute, however, was provisional and the women were striving to have a real convent. The short office of Our Lady would be replaced by the long one, complete poverty would be introduced, the three solemn vows would be compulsory and there would be an enclosure. ${ }^{38}$ Canonically Maria Petyt remained secular, to Michael of St. Augustine a cloistered sister in the making.

32 Mechelen, Stadsarchief, Archieven van het rijksarchief Antwerpen in bewaring gegeven, Geschoeide karmelieten van Mechelen, 2, fol. 36r-37r; Mechelen, Stadsarchief, Archieven van het rijksarchief Antwerpen in bewaring gegeven, Geschoeide karmelieten van Mechelen, 5, 308. Mechelen, Stadsarchief, Oud archief, geschoeide karmelieten, Q, 1, fol. 36-1.

Contract dated 4 December 1655; Mechelen, Stadsarchief, Archieven van het rijksarchief Antwerpen in bewaring gegeven, Geschoeide karmelieten van Mechelen, 5, 307.

34 Ordonnantiën, fol. $3 v / 4$ r.

35 In Maria's autobiography she writes 'den eersten Reghel van onse Lieve Vrauwe des Berghs Carmeli, in eenighe maniere verschillende vande onderhoudinghe vande ongheschoeyde Carmelitessen, meer conform aen de onderhoudinghe vande HH. Euphrasia, ende Euphrosina.' Petyt (1683) vol. 1, 97.

36 Ordonnantiën, fol. $9 \mathrm{v}$.

37 Petyt (1683) vol. 2, 327f.

$38 \quad$ Ordonnantiën, fol. $7 \mathrm{v}-8 \mathrm{v}$. 


\section{The Hermits of De Cluyse}

The hermitage never became a big community. There were always fewer than a dozen members. ${ }^{39}$ To outsiders it seemed so ascetic and strict ${ }^{40}$ that many candidates were scared off. Although we know that some women entered, we also have records of people leaving the hermitage. The hermitage lasted no longer than 70 years, with three mothers superior. The last one, Françoise Engrand, ${ }^{41}$ knew the first, Maria Petyt. After her death in 1724 the hermitage was rented privately. ${ }^{42}$ The sisters had to combine various functions in order to manage their life. ${ }^{43}$ The mistress of the novices had time to take on additional duties. However, Maria Petyt, who provided spiritual guidance, felt overworked. Michael confirmed this and assisted Maria for a while. ${ }^{44}$ But her stress was caused by the actual burden of the guidance, not by the numbers of candidates.

Of some sisters we know only their names, of others their origins, their financial status, their personalities. Of course, we know Maria Petyt best, but her fellow sister and successor Catharina van Orsaghen has remained fairly unknown to this day. ${ }^{45}$ We suppose that her reputation was as good as Maria's. ${ }^{46}$ She dreamed a lot and had anti-Jansenist visions, which many Carmelites respected. ${ }^{47}$ Françoise Engrand made some excellent investments. ${ }^{48}$

39 Persoons (2009) 276-277 compiled a list of 13 members and Staring (1948) $302 \mathrm{f}$ adds some other names. In the quoted letter of Michael of St. Augustine, n. 8, the hermitage had 8 or 9 members, 2 servants and 4 filiae devotae, with prospects of 3 postulants.

40 'in rigidissima nostrarum Tertiarum congregatione Mechlinia', Timothy of the Presentation (1926), VII-XV.

41 She was buried in the church of the Carmelites, like Maria Petyt and Catharina van Orsaghe, Antwerpen, Stadsarchief / Felixarchief, $K K$ (Kerken en kloosters), 1493, 72.

Mechelen, Stadsarchief, Archieven van het rijksarchief Antwerpen in bewaring gegeven, Geschoeide karmelieten van Mechelen, 6, 91.

43 Ordonnantiën, fol. 1or-12v.

44 In a letter to Françoise Engrand, quoted by Deblaere (1979) 45 .

45 Cf. our contribution, n. 9.

46 Mechelen, Stadsarchief, $c c$, 31, s.f. (The diary notes the death of Catherina but not of Maria Petyt!); Petyt (1683) vol. 2, 378f.

Het leven van de seer Edele Doorluchtighste en H. Begga (1712) 485f; Ceyssens (1953) 97. All but one of the approbaters of Het leven vande weerdighe moeder Maria a S.ta Teresia, (alias) Petyt (1683-1684) were members of the secret anti-Jansenist association, Ceyssens (1950) 363-367.

48 E.g. Boxmeer, Nederlands Carmelitaans Instituut, Provincia Flandro-Belgica, convent of Mechelen. 
Some sisters came from families of the Great Council, others had humbler backgrounds. Maria Petyt was from a prosperous merchant family. Catherina was the daughter of a wealthy pharmacist. ${ }^{49}$ She was a Beguine before she entered the hermitage. Sister Hannes, a widow, was given a small sum of money by Maria Petyt in order to be able to enter the hermitage. ${ }^{50}$

This group probably had the same clothing, the same rules and the same ideal, and to the outside world the sisters probably lived like angels. Yet angels have wings and when flying some feathers are lost. There were internal tensions in the community life, however restricted this life was. ${ }^{51}$

When entering the hermitage, the sisters brought their own possessions with them. This money was managed by the mother superior and the priest who acted as spiritual director. They did not invest in land but in pensions. ${ }^{52}$ Sometimes they invested in a house. On 14 February 1660 Maria Petyt and Catharina van Orsaghen were registered in the general ledger of Brabant for a hereditary pension of $12 \mathrm{fl}$. per annum..$^{53}$ Later this money went to the hermitage and, in 1724, to the Carmelites of Mechelen: the hermitage in Termuylen had meanwhile become a real cloister. ${ }^{54}$

\section{The Physical Life}

In this section we describe a typical day in the lives of the sisters in the hermitage. We start with their physical life, the life of the body, realising that it is inseparable from their spiritual life.

We have access to a very precise schedule. ${ }^{55}$ The sisters prayed their night prayer: they got up at midnight and went back to their cells at 1 a.m. They were

49 Het leven van de seer Edele Doorluchtighste en H. Begga (1712) 480.

$5^{0}$ Boxmeer, Nederlands Carmelitaans Instituut, Provincia Flandro-Belgica, convent of Mechelen: act of 9 September 1707 .

$5^{1} \quad$ Petyt (1683) vol. 2, 67-69, 1566 .

$5^{2}$ Ordonnantiën, fol. $9 \mathrm{r}-10 \mathrm{r}$

53 Boxmeer, Nederlands Carmelitaans Instituut, Provincia Flandro-Belgica, box 1: act of 14 February 166o, cf. Mechelen, Stadsarchief, Archieven van het rijksarchief Antwerpen in bewaring gegeven, Geschoeide karmelieten van Mechelen, 11, fol. 36r -37r; Mechelen, Stadsarchief, Archieven van het rijksarchief Antwerpen in bewaring gegeven, Geschoeide karmelieten van Mechelen, 5, 113; Mechelen, Stadsarchief, Archieven van het rijksarchief Antwerpen in bewaring gegeven, Geschoeide karmelieten van Mechelen, 6, 65.

54 Bronselaer (1945) 43 .

55 Ordonnantiën, fol. $2 r-3$ r. This schedule would change if the sisters adopted the statutes of a cloistered order. The great canonical office would shift the return to the cell to 2 a.m. 
woken again at 4 a.m. They went to sleep around 8 p.m. ${ }^{56}$ Thus they had about seven hours' sleep. Maria Petyt wrote that sometimes, the night prayer brought on a certain weakness so she had to be taken back to her cell. ${ }^{57}$

Immediately after getting up in the morning the sisters had time to read and to tidy their rooms. They were also expected to take turns cleaning the hermitage once a week. ${ }^{58}$ The detailed instructions concerning clothing might have been meant to avoid confusing the sisters with actual convent sisters like the Carmelites. By and large one could say that outside the hermitage the sisters looked like any other spiritual daughter. Inside the hermitage the rules concerning clothing were a bit more flexible. When possible shoes were replaced by slippers. 59

After the morning chores the sisters went to two masses in the church. Until 11 a.m. they were allowed to do work that was not distracting. Their handwork was sold or used for catechism or liturgical purposes. ${ }^{60}$

At 11.30 a.m., after an examination of conscience, each sister ate her meal in her cell. This was followed by solitary recreation in the garden, either reading, writing or sewing. ${ }^{61}$ We learned that Maria translated letters and also wrote a lot. ${ }^{62}$ From 1 p.m. until 5 p.m. the sisters remained in their cells where they interrupted their work periodically for vespers and prayer. ${ }^{63}$ After communal prayer in the oratory the sisters went back to their cells for supper. The communal night prayer was at 7.30 p.m.; twice a week it was followed by confession, spiritual instruction by the mother superior and her individual guidance. She had to visit her daughters in their cells at least twice a week. ${ }^{64}$

Although the sisters ate in their cells most of the time, on Sundays they ate in the refectory. At night it was usually bread and butter and fruit, and at noon soup with some bread. The fruits were selected carefully; meat and fish were excluded. Sometimes the sisters ate eggs. Beer regularly accompanied the meal. Wine was not allowed, except in cases of sickness. ${ }^{65}$ Luckily there were

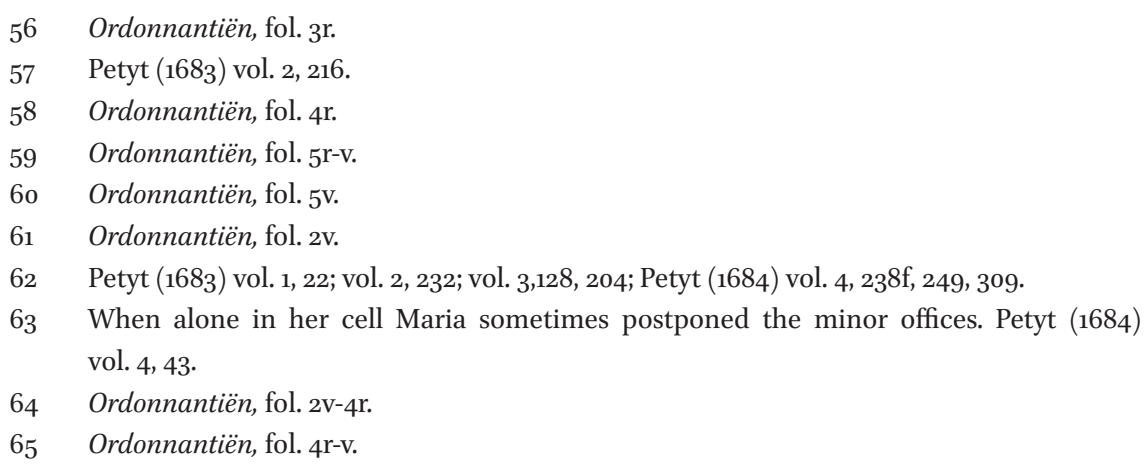


exceptions to that rule. Maria Petyt did drink a goblet of wine during the carnival. ${ }^{66}$ Fasting was very strict, but feasts were allowed from time to time.

\section{The Spiritual Life}

All these physical constraints have to be understood in the context of Maria Petyt's striving for a life of intimacy with God. If we are not aware of this aim, we cannot understand her writings or her ascetic life. To reach her goal the accent was on solitude, silence and prayer.

Solitude was achieved by spending a lot of time alone in her cell, a minimum of refectory and recreation time, and a maximum of silent prayer. We shall not dwell on this subject. However, there was one difficulty: the outside world. In principle the sisters were only allowed to go out at Easter for the Easter service in the parish church. ${ }^{67}$ Yet Maria Petyt made some exceptions, for example during a jubilee at St. Rumbold's cathedral. ${ }^{68}$ The sisters had to go out in pairs. On these outings Maria picked up all sorts of news, with the result that her prayers always had a very human character of intercession. ${ }^{69}$ Other sisters went out, too, for instance for shopping, particularly when there was no special sister for these tasks. ${ }^{70}$ However, there were also contacts with the outside world inside the hermitage. These took place in the parlour, with another sister to witness the conversation. ${ }^{71}$

The sisters' ordinances and writings testify to a profound wish to participate in the 'great silence of the Carmelites'. ${ }^{72}$ However, this inner attitude had to go hand in hand with outward silence. This was not always possible, and Maria complained that her sleep was disturbed by the noisy youth of Mechelen. ${ }^{73}$

Concerning prayer, we have to confine ourselves to its outward characteristics. First we need to comment on their reading. Maria and her sisters read the little office of Our Lady but in the ordinances Michael of St. Augustine writes that the sisters may read, when recognized as an enclosed convent, the ordinary choral prayer ${ }^{74}$ Maria did not have to strain to read the office with her by

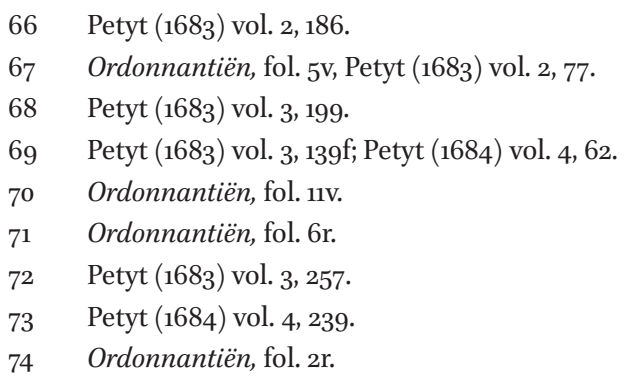


now healed eyes: she knew the prayers by heart. ${ }^{75}$ After the night office the sisters practised self-flagellation.

In church the sisters attended two masses and received communion daily after the first mass. ${ }^{76}$ Witnesses noticed Maria Petyt's intense devotion during this communion. Others commented on her attitude during the adoration, where she would sometimes stay for hours. ${ }^{77}$ Occasionally Maria had a sudden impulse to receive communion from any priest who happened to be available at that moment. ${ }^{78}$ Once or twice a week the sisters went to confession. ${ }^{79}$ Once in a while they were allowed to confess to a priest they did not know. Spiritual guidance by priests other than Carmelites was not totally prohibited, but it was not encouraged in order to avoid getting lost in all sorts of spiritualities. ${ }^{80} \mathrm{In}$ this way the inner life of some sisters became such an intense union with God that it seemed to merge into eternal life.

When entering the hermitage the sisters were allowed to choose where they wanted to be buried. ${ }^{81}$ However, the funeral service had to be held in the parish church first. Maria probably chose the Carmelite church, where she remained buried until the French revolution. Other sisters followed her example. ${ }^{82}$ To date no relics of these bodies have been found. Who would think when climbing the stairs to the huge metropolitan church of Mechelen today that some of these steps are the gravestones of the sisters of the old hermitage? ${ }^{83}$

Michel van Meerbeeck ( ${ }^{\circ}$ Antwerp 1954) studied history at Ghent University and carried on his studies in theology in Liège where he was ordained priest (1986). In the year 2000 he earned the degree of doctor in history of the KU LEUVEN with a thesis about Ernest Ruth d'Ans, secretary of the Grand Arnauld. This was published in 2006 in the Library of the Revue d'histoire ecclésiastique.

At present he is a collaborator at the Center for the Study of Augustine, Augustinianism and Jansenism of the Faculty of theology (KU LEUVEN) where he is preparing a study of Bishop Soanen of Senez's pastoral activity.

\footnotetext{
$75 \quad$ Petyt (1683) vol. 2, 324 .

76 Justification in Ordonnantiën, fol. 7 r.

77 Timothy of the Presentation (1729) 5, 4-7.

78 Petyt (1683) vol. 3, 249. In that time and district, it was common for anchoresses to receive communion frequently (every day).

79 Ordonnantiën, fol. 7r-v. Maria Petyt had many confessors. Petyt (1683) vol. 1, 200.

$80 \quad$ Ordonnantiën, fol. $7 \mathrm{v}$.

$81 \quad$ Ordonnantiën, fol. 8 r.

82 Antwerpen, Stadsarchief / Felixarchief, $K K$ (Kerken en kloosters), 1493, 65-78.

83 The gravestones were used for the restoration of the main entrance of St. Rumbold's Cathedral.
} 


\section{Archives}

Antwerpen, Felixarchief (Stadsarchief), $K K$ (Kerken en kloosters), 1493: [Norbertus a Sancta Juliana], Conventus Mechliniensis, primum fundate in Neckerspoel, deinde translati intra muros Civitatis, nunc sub titulo Sancti Patris Nostri Eliae Prophetae, antiqua \& novissima descriptio.

Boxmeer, Nederlands Carmelitaans Instituut,

[1] Provincia Flandro-Belgica, s.n.: Box 1, varia;

[2] Provincia Flandro-Belgica, s.n.: Conventus Mechelen;

[3] Provincia Flandro-Belgica, s.n.: Conventus Liedekerke.

Gent, Rijksarchief, Oud notariaat, 1270: Notaris A. Vanden Broecke (1652-1655).

Leuven, KADOC, Provinciaal archief van de Vlaamse Minderbroeders, 2.2.291: J. van Meerbeek, Register ende specificatie van allen de landen, bemden, bosschen, aerden ende opstallen der convente vande Patres Carmeliten binnen Mechelen toebehoorende (1653).

Mechelen, Archivum archiepiscopalia,

[1] Oud parochiearchief, St. Servaas, Schaarbeek, kluis van St. Servaas: s.n.: Ordonnantien voor de heremitagie der susteren van de Alderheylighste Maget Maria des Berghs Carmeli. Aen hun door Godts ingeven voorgeschreven door den seer eerweerdighe pater Michael a Sancto Augustino, provintiael der Nederduytsche provintie der eerweerdighe paters carmeliten onse lieve vrauwe-broeders in't jaer 1660. Geapprobeert door den seer eerweerdighsten pater Marius Venturinus, generael van de voorseyde order ende apostolischen visiter der carmeliten, op den vijffden january 1660 . Until the publication, we refer to the original folios of this document.

[2] Oud parochiearchief, St. Servaas, Schaarbeek, kluis van St. Servaas, s.n.

[3] Conventualia, Geschoeide karmelieten van Mechelen, 20: cijnsregister.

Mechelen, Stadsarchief,

[1] Archieven van het Rijksarchief Antwerpen in bewaring gegeven, Geschoeide karmelieten van Mechelen: 1 Copies of acts of the convent, 5 Manuaelboeck, 6 Nieuwen registerboeck, 11 Inventory of the archives.

[2] Augustijnen, 40 B: act of the alderman (1613).

[3] Oud archief, Geschoeide karmelieten van Mechelen, cc, 31: Necrologium Carmeli Mechliniesis; Ex diario Carmeli Mechliniensis.

[4] Oud archief, Geschoeide karmelieten van Mechelen, Q, 1: Brocardus a Sancto Flugentio, Liber depositi Carmeli Mechliniensis ab anno 1584.

Rome, Archivum generale ord. Carmelitarum, II Provincia Flandro-Belgica, s.n.: Convent of Brussel.

* (without signature = s.n.). 


\section{Bibliography}

Adriaensen, L. 1988. Een Mechelse pastoor ten onder in de Waddenzee. De oecumenische en economische avonturen van pater Christiaen de Cort. In Handelingen van de koninklijke kring voor oudheidkunde, letteren en kunst van Mechelen, vol. 92, 104-116.

Bronselaer, M. 1945. Geschiedenis van het klooster en O.L.Vrouw-ter-Muylen te Liedekerke. Antwerpen: Altiora.

Constitutiones. 1656. Constitutiones strictioris observantiae pro Reformatis in ordine Carmelitarum Appprobatae,\& confirmatae ab Urbanae VIII. Cum Articulis ab Innocentio X. adiunctis \& approbatis, propriisque locis, ex illius mandato, insertis Ex decreto capituli generalis Romae celebrati anno MDCXLV. Antverpiae, apud Jacob Meursium, Anno MDCLVI.

Ceyssens, L. 1950. Een geheim bondgenootschap ter bestrijding van het jansenisme in België. In L. Ceyssens, Jansenistica, vol. 1, 363-367. Mechelen: Franciscusdrukkerij.

Ceyssens, L. 1953. De Carmelitarum Belgicorum actione antejansenistica iuxta chartas P. Seraphini a Jesu Maria (1668-1688). In L. Ceyssens, Jansenistica minora, vol. 2. 1-120. Mechelen: Franciscusdrukkerij.

Daniel of the Virgin Mary (Daniel à Virgine Maria). 1646. Af-beeldinghe van de derde orde onser L. Vrouwe des Berghs Carmelus. Door P. F. Daniel a Virgine Maria Lees-meester in de H. Godtheijt ende Supprior der Carmeliten te Brussel. T'Antwerpen bij de weduwe van Ian Cnobbaert.

De Baar, M. 2004. 'Ik moet spreken'. Het spiritueel leiderschap van Antoinette Bourguignon (1616-1680). Zutphen: Walburg Press.

Deblaere, A. 1962. De mystieke schrijfster Maria Petyt (1623-1677). (Koninklijke Vlaamse Academie voor Taal- en Letterkunde. vide reeks. Bekroonde werken, vol. 87). Gent: Secretarie der Academie.

Deblaere, A. 1979. Maria Petyt, écrivain et mystique flamande (1623-1677). In Carmelus, vol. $26,3-76$.

Deblaere, A.1980. Michel de Saint-Augustin, carme. Dictionnaire de spiritualité, ascétique et mystique. vol. X. c. 1187-1191. Paris: Beauchesne.

Het leven van de seer Edele Doorluchtighste en H. Begga. [1712]. Het leven van de seer Edele Doorluchtighste en H. Begga, hertoginnevan Brabant, Stighteresse der Beggynnen. Met een Cort Begryp van de Levens der Salige, Godtvruchtighe en Lof-weerdige Beggyntjens der Vermaerde en Hoog-gepresen Beggijnhoven, by een vergadert door eenen onbekende Dienaer Godts. [1712]. T'Antwerpen, By de Weduwe van Petrus Jacobs, woonende inde corte Nieuw-straet, inder witten Leeuw.

Hoppenbrouwers, V. 1934. Daniël de la Vierge Marie. In Dictionnaire de spiritualité ascétique et mystique, vol. III., c. 19-20. Paris: Beauchesne.

Hoppenbrouwers, V. 1949. Michael van de Heilige Augustinus. In Carmel, vol. 2, $155^{-173}$

Hoppenbrouwers, V. 1960. Devotio mariana in Ordine Fratrum B.M.V. De Monte Carmelo a medio saeculi XVI usque ad finem saeculi XIX. Romae: Institutum Carmelitanum. (Collationes mariales Instituti carmelitani, vol.1) 
James of the Passion (Jacobus a Passione Domini). 1681. De stralen van de sonne van den H. Vader en Propheet Elias, dese eeuwe verspreydt door Duitsch-landt en Neder-landt. Dat is: De Levens van eenighe Religieusen, van de Orden der Broederen, van de Alderheylighste Maghet Maria des Berghs Carmeli, die dese 17.de Eeuw met opinie van Heylighheydt, al-daer zijn over-leden. Uyt verscheyde Autheurs in't kort by-een vergadert, en met Fyne Platen verciert, door den Eerw. P. F. Jacobus a Passione Domini, Priester in de selve Orden. Aen-nemen de Deughden van de Deughdelijcke, is het alder-salighste leven. Seneca in Epist. Tot Luyck, By Hendrick Hoyoux, in den H. Franciscus Xaverius.

Kort begryp van de historie. [1758]. Kort begryp van de historie, ende oorspronck der capelle, ende kercke van Onse Lieve Vrouwe ter Muylen, gelegen in de baronie van Liedekercken. Van het miraculeus beeldt der Alder-heylighste maget en Moeder Godts Maria het welck aldaer ge-eert wordt ende van de devotien die aldaer ghepleegtworden mitsgaders eenige devote bemerckingen ende gebeden om de geloovige te verwecken tot de devotie van Maria. Tot Brussel: bij Carolus de Vos, Stadt-drucker, op de Kole-Merckt.

Laenen, J. 1912-1914. Inventaire sommaire des archives de l'archevêché. In Annuaire du clergé de l'archevêché de Malines, vol. 16, VII-XVIII, vol. 17, VII-XVIII, vol. 18, VII-XXII.

Lowyk, A. 1991. Nederlandstalige schrijvers in Hazebroek, Westhoek van de Nederlanden in Frankrijk. Poperinge: Werkgroep de Nederlanden.

Martinez Carretero, I. 1991. Figuras del Carmelo In Los Carmelitas. Historia de la Orden del Carmen, vol. 6. Madrid: Biblioteca de Autores Cristianos.

Melchior a Sancta Maria. 1968. Vier eeuwen Discalsen. 1568-1968. Geschiedkundig overzicht van de Theresiaanse hervorming. Zeldzame drukken, handschriften en voorwerpen. Gent: Covent of the discalced carmelites.

Michael of St. Augustine (Michael à S. Augustino). 1681. Kort Begryp van het Leven van de Weerdighe Moeder Sr. Maria a S. Teresia, (alias) Petyt, Gheestelijcke Dochter, van den Derden Regelvan de Orden der Alder-glorieuste Maghet Maria des Berghs Carmeli; over-leden met opinie van Heyligheydt, binnen Mechelen, den I. Novemb. 1677. Getrocken uyt haer Leven, in het langh en breeder beschreven: door den seer Eerw. P. F. Michael a S. Augustino, Provinciaelvan de Neder-landtsche Provincie der Eerw. PP. Lieve-VrouweBroeders. Menvindt-se te koope, Tot Brussel, by Peeter Vande Velde, op den hoeck van de Munte, in de nieuwe Druckerye.

Motta Navarro, T. 1960. Tertii Carmelitici saecularis ordinis historico-iuridica evolutio. Romae: Institutum Carmelitanum (Textus et studii carmelitana, vol. 4).

Panzer, S. 2006. Observanz und Reform in der belgischen Karmelitenprovinz. 1623-1649. 'Pour parvenir à un parfait rétablissement de la discipline régulière'. Roma: Edizioni Carmelitane. (Textus et studia carmelitana, vol. 25).

Persoons, E. 2009. Derdeordelingen van de karmelietenorde te Mechelen. In Handelingen. Koninklijke Kring voor Oudheidkunde, Letteren en Kunst van Mechelen, vol. 113 (2009) 277-280.

Petyt, Maria. 1683-1684. Het Leven van de Weerdighe Moeder Maria a Sta. Teresia, (alias) Petyt, Vanden derden Reghel vande Orden der Broederen van Onse L. Vrouwe desBerghs Carmeli, Tot Mechelen overleden den I. November 1677. Van haer uyt ghehoorsaemheyt, ende goddelijck ingheven beschreven, ende vermeerderinghe, van 't selve Leven. Uyt 
haere schriften ghetrocken, ende by een vergadert door den seer Eerw. P. Michaël a Sancto Augustino, Provinciael vande Paters onse Lieve Vrouwe Broeders des Berghs Carmeli, inde Neder-duytsche Provincie. Volvan volmaeckte deughden, om naer te volghen, van goddelijcke jonsten, verlichtighen, ende bewerckinghen om van te verwonderen, ende Godt te loven. Van alderleye onderwysinghen tot de volmaecktheyt voor de beghinnende, voortgaende, ende volmaeckte. Godt is wonderlijck in sijne Heylighen. Psalm. 67. 36. Te Ghendt, Gedruckt by de Hoirs van Jan Vanden Kerckhove, op d'Hooghpoorte in't ghecroont Sweerdt. 4 vol.

Possanzini S. 1998. La dottrina e la mistica mariana del ven. Michele di S. Augustino, carmelitano. Roma: Edizioni Carmelitane. (Institutum carmelitanum. Collationes mariales, 2)

Sainsaulieu, J. 1974. Les ermites français. Paris: Cerf.

Sanderus, A. 1727. 'Chorographia Sacra Celebris \& Antiqui Monasterii S. Patris Eliae, Ordinis Fratrum beatissimae Virginis Mariae de Monte Carmelo Mechliniae.' In Sanderus, A. Chorographia Sacra Brabantiae, sive celebruim aliquot in ea provincia abbatiarum, coenobiorum, monasteriorum, ecclesiarum, piarumque fundationum descriptio. Ex Monasteriorum Tabulis, é Principium Diplomatibus, suis locis insertis, eruta, et imaginibus aeneis illustrata, tomus secundus. Hagae Comitum, Apud Christianum van Lam, Bibliopolam, MDCCXXVII,221-244.

Staring, A. 1948. Een carmelitaanse kluizenares. Maria Petyt a S. Theresia. In Carmel, vol. 1, 287-305.

Timothy of the Presentation (Timotheus a Praesentatione). 1727-1729. Brandende lampen voor het Alderheylighste Sacrament des Autaers ofte de doorluchtige lief-hebbers van dit goddelijck mysterie, tot naervolginge voorgestelt, ende verdeelt op alle de dagen des jaers, met geestelycke Leeringen, seer profytigh voor Predicanten, Priesters, en voor alle Staten van Menschen, maer besonderlijckvoor alle Godt-soeckende Zielen: als oock seer aengenaem om te lesen, om de wonderheydt, verscheydentheydt en nieuwigheydt van de Levens ende Exempelen hier in begrepen. Doorden Eerweerdigen Pater Timotheus a Presentatione B.V.M., Relighieus van de Orden van Onse Lieuve Vrouwe des Berghs Carmeli, van de Vlaemsche Nederlandsche Provincie. T'Antwerpen, by Petrus Jouret, Stadtsdrucker, ende van Sijne Doorluchtighe Hoogweirdigheydt, op de Melck Merckt in de gulde Tralie, 5 vol.

Timothy of the Presentation (Timotheus a Praesentatione). 1926. 'Vita Ven. P. Michaelis a S. Augustino.' In Michael a Sancto Augustino. Introductio ad vitam internam et fruitiva praxis vitae mysticae. Romae: In Collegio S. Alberti, VII-XV.

Valabek, R. 2008. Michele di Sant' Augustino. In Boaga, E., Borriello, L. eds. Dizionario carmelitano. 577 f. Roma: Cittá nuova.

Wijnhoven, D. 1966. Enige voorlopige opmerkingen omtrent Daniel a Virgine Maria en zijn provincie. In Jonge Karmel, vol. 25, 61-95. 